\title{
Maturation responses of salmonids to changing developmental opportunities
}

\author{
John E. Thorpe* \\ University of Glasgow, Institute of Biomedical and Life Sciences, Glasgow G12 8QQ, UK
}

\begin{abstract}
Maturation is the allocation of energy to growth and differentiation of germinal tissue to the ultimate production of gametes. In Atlantic salmon Salmo salar, maturation begins in the egg soon after fertilisation and continues intermittently until the individual is capable of spawning. Completion of the process depends on exceeding genetically determined biochemical thresholds (lipid status) in critical seasons (through responsiveness to photoperiod cues). Hence, maturation is regulated by inhibition, and age and size at maturity depend on physiological efficiency (genetic endowment) and developmental opportunity (environmental context). This interaction of genetic diversity and developmental flexibility leads to multiple maturation trajectories (up to 32 in steelhead trout Oncorhychus mykiss) and wide variation in age and size at spawning. Severe depletion of a Kamchatka sockeye salmon Oncorhychus nerka population through $50 \mathrm{yr}$ of oceanic fishing resulted in increasing proportions maturing rapidly at small size before emigration from freshwater. In the absence of such a fishery, genetic evidence suggests that stabilising selection would ultimately restore the anadromous, slower-maturing pattern as the predominant life style to such a stock.
\end{abstract}

KEY WORDS: Maturation · Salmon $\cdot$ Control by inhibition $\cdot$ Fishing effects $\cdot$ Stabilising selection Resale or republication not permitted without written consent of the publisher

\begin{abstract}
MATURATION
Maturation is a process of allocating energy during development to the growth and differentiation of germinal tissue into gonads and to the ultimate production of ripe gametes. In teleosts, it starts within hours or days after fertilisation of the egg, and in the Atlantic salmon Salmo salar L. for example, gonadal tissue begins to appear during the early embryo stage (Adams \& Thorpe 1989). Thereafter, maturation proceeds intermittently over a period of years until the fish is finally capable of spawning. 'First maturity', as an event for the population biologist, identifies the culmination of the process rather than the process itself. Age-at-first-maturity and size-at-first-maturity are misleading measures, because they appear to suggest that steps towards this state of reproductive ripeness have not taken place until a specific age or size is reached at which spawning can occur. Indeed, both age and size as thresholds are concepts that are prob-
\end{abstract}

ably undetectable to a fish - how does a fish know how old or how large it is (Thorpe 1986)? The fish's developmental decisions are likely to be based on proximate cues, both internal and external, largely independent of size and age.

\section{CONDITIONAL RESPONSES}

If it was not already evident from the wild, the physiological flexibility of the maturation process has been demonstrated abundantly in aquaculture, where maturity has been accelerated or delayed both environmentally and genetically, at ages, sizes and seasons spanning and exceeding those recorded in the wild, to suit the needs of the cultivator. The opportunistic element in this was expressed well by Policansky (1983), who noted that '...under stable conditions with abundant food, [fishes] should grow rapidly and mature as soon as they are developmentally able to do so'. 
Typically, fish populations respond to heavy exploitation with a reduction in both the age and the size at which the average individual completes sexual maturity (e.g. Ricker 1981). The rapidly reduced density of older, larger fish is presumed to enhance opportunities for development of younger, smaller individuals. Increased developmental rate is associated with earlier maturation at smaller size, and continued removal by the fishery of older, larger fish provides the opportunity for natural selection to favour earlier maturity (Thorpe 1993). There is also evidence of environmentally induced changes independent of fisheries in the rates and sizes at which fish achieve reproductive success in the wild (Bigler et al. 1996, Pyper \& Peterman 1999), in particular, decreases in size and increases in age associated with increases in abundance.

\section{ENVIRONMENTAL CONTEXT OF MATURATION}

Currently, much effort is being expended on exploring variation in maturation rates, using the maturation reaction norm (the age-specific body size at which $50 \%$ of individuals become mature) and attempting to partition its variance into environmental and genetic components. However, the utility of this approach is questionable, since it is largely a statistical exercise on ultimate data that does not take into account the proximate physiological processes involved. Maturation is a cyclic process. In Atlantic salmon, completion of maturation with the production of ripe gametes within the first annual cycle is physiologically possible but infrequent, being limited apparently by lipid resources in the spring (Rowe \& Thorpe 1990, Rowe et al. 1991, Simpson 1992, Arndt 2000). If lipid reserves in the spring are insufficient, further gonadal investment is arrested until the anniversary of fertilisation in the autumn. Then, given adequate lipid reserves, investment in gonadal tissue will start again (Thorpe 1994a). Provided that lipid stores remain sufficiently high throughout the winter, and can be replenished during a period of rapid growth in the spring, maturation will be maintained and the individual will be fully mature by the following November. If lipid stores are depleted over the winter to a level where they cannot be replenished in the spring, further gonadal investment is inhibited and maturation is postponed for another year. This response has been exploited in aquaculture to postpone maturation and increase somatic growth (Thorpe et al. 1990, Reimers et al. 1993). This control of maturation by successive inhibition through lipidregulated switches continues until such time as the appropriate lipid thresholds are achieved in the critical seasons of autumn and spring, when progress to the complete development of ripe gonads and gametes can be completed.

Such a physiological process, played out in a range of environments, allows for a wide range of ages and sizes at final maturity and repeated ripenings in later years (Thorpe et al. 1998, Rikardsen et al. 2004). For example, there may be up to 32 distinguishable developmental trajectories to completion of maturity in 1 generation of steelhead trout Oncorhynchus mykiss Walbaum (Thorpe 1998). The fish will mature if the rate of acquisition of surplus energy during a critical period exceeds a genetically determined threshold. By this concept of maturity, temporal and spatial differences in adult sizes and ages depend on the physiological efficiency (i.e. genetic endowment) and developmental opportunity (environmental context) taken by individuals.

\section{PHENOTYPIC AND GENOTYPIC CONSEQUENCES OF FISHING}

The maturation process and the impact of fisheries upon it can be illustrated among Pacific salmonids. Typically, juveniles develop at first in fresh water and then emigrate, with a major growth phase at sea prior to returning to spawn in fresh water after 1 or more years. Heavy exploitation at sea leads to earlier maturity, presumably at first through reduced density and correspondingly improved developmental opportunity for the survivors. From a $50 \mathrm{yr}$ study of a population of sockeye salmon Oncorhynchus nerka Walbaum in Lake Dal'neye, Kamchatka, Krogius (1979) and Varnavskaya \& Varnavsky (1988) showed that the number of spawners returning from the sea decreased progressively from 62000 per annum in the 1930s to only 4500 by the $1980 \mathrm{~s}$, as oceanic exploitation of maturing adults increased. The same pattern was recorded in several other Kamchatka sockeye populations over this period. With the decrease in returning fish, so the progeny populations in Lake Dal'neye decreased also. However, as sockeye density in the lake decreased, so zooplankton availability increased and with it individual development rate of juvenile sockeye here and in neighbouring lakes (Nikulin 1970). Progressively higher proportions of male sockeye matured rapidly in fresh water at small sizes as 'residents' (10 or more times smaller than sea-run adults), while their slower developing siblings emigrated to sea, providing evidence of association of improved developmental opportunity with early maturation. This tactic is seen more frequently in male salmonids, for whom maturation is energetically less expensive than it is for females. However, in Lake Dal'neye, eventually even female sockeye were maturing early at small sizes as 
residents, so that by the mid-1980s residents accounted for $91.8 \%$ of the spawning population of males and $43.2 \%$ of the females. Hence, the maturation reaction norm that would have been associated with the typical anadromous behaviour of the species would have been representative no longer, because there were now not 1 but 2 sets of size distributions from which the norms would have been derived.

Beside this dramatic phenotypic change, Krogius (1979) also noted evidence of genetic change in the Lake Dal'neye stock. Altukhov \& Varnavskaya (1983) and Altukhov \& Salmenkova (1991) examined a number of sockeye stocks in Kamchatka and found greatest variation among them to be at the Pgm locus. Within the Lake Dal'neye population, heterozygosity at the Pgm locus in spawning resident males was 0.62 compared with 0.30 and 0.31 in 2 seasonal groups of older larger males returning from the ocean. Similar biases towards high heterozygosities were recorded from spawning resident males in Lakes Nachikinskoye and Blizhneye compared with larger, older sea-run males. Altukhov \& Salmenkova (1991) concluded that the fishery was selecting heavily against the larger, less heterozygous males and in favour of the more heterozygous residents.

From independent experiments with pink salmon Oncorhynchus gorbuscha Walbaum with progeny sets from 8 different combinations of allozymes at 4 loci, Altukhov et al. (1991) showed that while high heterozygosity was associated with high developmental rate, the progeny of parents of average heterozygosity survived better than did those of high or low. They concluded that directional selection driving such populations towards a preponderance of smaller, earlier maturing, but highly heterozygous types would threaten population stability through reduced vitality. Hence, such populations might decline at a rate faster than could be attributed directly to fishing alone.

\section{CONTROL OF MATURATION BY INHIBITION}

Recent research by Aubin-Horth et al. (2005) revealed brain gene expression in Atlantic salmon that provides independent support for the physiological model of control of maturation by inhibition. The brain gene expression profiles suggested that delayed maturation and sea migration of immatures, the 'default' life cycle, resulted from an active inhibition of maturation, so that the emigrant juveniles represented the fish that had failed to complete maturity in that year (as was pointed out earlier, on independent physiological grounds, by Thorpe [1994b]). Since the overwhelming number of populations of Atlantic salmon are anadromous, and residency is numerically subsidiary to anadromy within those populations, this inhibition of maturation may be a genetic stabilising mechanism, favouring average rather than high or low heterozygosity (Altukhov 2006), and inhibiting Atlantic and other salmon populations from evolving toward residency. This would be a further reason for caution in focussing exploitation on the slower-developing, larger members of salmon populations, to avoid disturbance of the stabilising influence of genetic diversity.

Empirically, it is clear that salmonids are capable of completing maturation in their first year, but that most individuals are inhibited from doing so. N. AubinHorth's work promises to reveal more about the genetic components of this inhibition. Some external and internal conditions promoting inhibition are understood, but the physiological mechanisms responsible for seasonal arrest and subsequent restoration of investment of energy into gonads are not. Until the endocrine patterns involved are unravelled, it will not be possible to disentangle environmental and genetic components of variation in maturation of these fishes.

Acknowledgements. I thank C. T. Marshall and H. Browman for inviting me to contribute to this Theme Section.

\section{LITERATURE CITED}

Adams CE, Thorpe JE (1989) Photoperiod and temperature effects on early development and reproductive investment in Atlantic salmon (Salmo salar L.). Aquaculture 79: 403-409

Altukhov YP (2006) Intraspecific genetic diversity. SpringerVerlag, Berlin

Altukhov YP, Salmenkova EA (1991) The genetic structure of salmon populations. Aquaculture 98:11-40

Altukhov YP, Varnavskaya NV (1983) Adaptive genetic structure and its connection with intrapopulation differentiation for sex, age and growth rate in sockeye salmon, Oncorhynchus nerka (Walbaum). Genetika 19:796-807

Altukhov YP, Salmenkova EA, Kartavtzev YF (1991) Relationship of allozyme heterozygosity with viability and growth rate of pink salmon. Tsitol Genet 25:47-51

Arndt SKA (2000) Influence of sexual maturity on feeding, growth and energy stores of wild Atlantic salmon parr. J Fish Biol 57:589-596

Aubin-Horth N, Landry CR, Letcher BH, Hofmann HA (2005) Alternative life histories shape brain gene expression profiles in males of the same population. Proc R Soc Lond B 272:1655-1662

Bigler BS, Welch DW, Helle JH (1996) A review of size trends among North Pacific salmon (Oncorhynchus spp.). Can J Fish Aquat Sci 53:455-465

Krogius FV (1979) On the relationship of the freshwater and seawater period of life of sockeye salmon in Lake Dal'neye. Biol Morya 3:24-29

Nikulin OA (1970) On the relationship between the decreased absolute numbers of sockeye Oncorhynchus nerka (Walb.) and the increased relative numbers of dwarfs among young fish feeding in Lake Uyeginsk. Izv TINRO 71:205-217 
Policansky D (1983) Size, age and demography of metamorphosis and sexual maturation in fishes. Am Zool 23:57-63

Pyper BJ, Peterman RM (1999) Relationships among adult body length, abundance and ocean temperature for British Columbia and Alaska sockeye salmon (Oncorhynchus nerka). Can J Fish Aquat Sci 56:1716-1720

Reimers E, Kjørrefjord AH, Stavøstrand SM (1993) Compensatory growth and reduced maturation in second winter farmed Atlantic salmon following starvation in February and March. J Fish Biol 43:805-810

Ricker WE (1981) Changes in the average size and average age of Pacific salmon. Can J Fish Aquat Sci 38:1636-1656

Rikardsen AH, Thorpe JE, Dempson JB (2004) Modelling the life-history variation of Arctic charr. Ecol Freshw Fish 13: 305-311

Rowe DK, Thorpe JE (1990) Suppression of maturation in male Atlantic salmon parr (Salmo salar L.) by reduction in feeding and growth during spring months. Aquaculture 86:291-313

Rowe DK, Thorpe JE, Shanks AM (1991) The role of fat stores in the maturation of male Atlantic salmon (Salmo salar) parr. Can J Fish Aquat Sci 48:405-413

Simpson AL (1992) Differences in body size and lipid reserves between maturing and non-maturing Atlantic salmon parr, Salmo salar L. Can J Zool 70:1737-1742

Editorial responsibility: Howard Browman (Associate Editorin-Chief), Storebø, Norway
Thorpe JE (1986) Age at first maturity in Atlantic salmon, Salmo salar: freshwater period influences and conflicts with smolting. Can Spec Publ Fish Aquat Sci 89:7-14

Thorpe JE (1993) Impacts of fishing on genetic structure of salmonid populations. In: Cloud JG, Thorgaard GH (eds) Genetic conservation of salmonid fishes. Plenum, New York, p 67-80

Thorpe JE (1994a) Reproductive strategies in Atlantic salmon. Aquac Fish Manag 25:77-87

Thorpe JE (1994b) An alternative view of smolting in salmonids. Aquaculture 121:105-113

Thorpe JE (1998) Salmonid life-history evolution as a constraint on marine stock enhancement. Bull Mar Sci 62: $465-475$

Thorpe JE, Talbot C, Miles MS, Keay DS (1990) Control of maturation in cultured Atlantic salmon, Salmo salar, in pumped seawater tanks, by restricting food intake. Aquaculture 86:315-326

Thorpe JE, Mangel MS, Metcalfe NB, Huntingford FA (1998) Modelling the proximate basis of salmonid life-history variation, with application to Atlantic salmon, Salmo salar L. Evol Ecol 12:581-599

Varnavskaya NV, Varnavsky VS (1988) On the biology of dwarf forms of sockeye in Lake Dal'neye (Kamchatka). Biol Morya 1988:16-23

Submitted: June 13, 2006; Accepted: December 8, 2006 Proofs received from author(s): February 28, 2007 